\title{
RÉPARTITION DE LA CHARgE POLLUANTE DU LISIER DE POHCHERIE EN FONCTION DE SES DIFFÉRENTS CONSTITUANTS PHYSIQUES. ÉTUDE D'UN DISPOSITIF DE TAMISAGE.
}

\author{
N. STAMBOULI et D. BALLAY* \\ Institut technique du Porc (détaché au C. T. G. R. E. F.) \\ * Centre technique du Génie rural des Eaux et des Forêts (C.T.G.R. E. F.), \\ Division Qualité des Eaux, Pêche et Pisciculture, \\ 14, Av. de Saint-Mandé, \\ 75012 Paris \\ RÉSUMÉ
}

Sur un échantillon moyen du rejet journalier d'une porcherie de naissagc-engraissement, nous avons déterminé et analysé les différentes fractions granulométriques dont la séparation a été effectuée par tamisage à des mailles allant de 40 à $800 \mu$ et, pour les particules de tailles inférieures à $40 \mu$, par centrifugation à $2200 \mathrm{~g}$ (pendant $15 \mathrm{mn}$ ).

On a pu ainsi montrer que les matières en suspension apportent une charge polluante notable (8o p. Ioo en DCO et 58,5 p. Ioo en $\mathrm{DBO}_{5}$ ) et que les particules les plus grossières apparaissent dans les mesures de $\mathrm{DCO}$ et MES mais affectent très peu la $\mathrm{DBO}_{5}$ et contiennent très peu d'azote. $\mathrm{La}^{\mathrm{DBO}}{ }_{5}$ est essentiellement liée aux matières dissoutes ou colloïdales et aux particules de tailles inférieures à $4^{\circ} \mu$.

En deuxième partie nous avons étudié les performances d'un tamis vibrant de type Contiscreen, fonctionnant en vraie grandeur, de $90 \mathrm{~cm}$ de diamètre et de $400-500 \mu$ de maille. Les conditions de fonctionnement optimales de ce type de tamis correspondent à une alimentation discontinue, à un débit aussi fort que possible pour constituer, à chaque période de fonctionnement, un gâteau de refus qui joue le rôle de précouche. Ce gâteau s'égoutte alors et s'évacue après l'arrêt de l'alimentation. Toutefois un débit trop fort ou une alimentation trop prolongée conduisent à un engorgement du tamis.

Ce type de tamis élimine 36 à $52 \mathrm{p}$. roo de matières solides qui représentent une charge en DCO de i à $\mathbf{I}, 2$ gramme par gramme. 


\title{
SUMMARY
}

\section{DISTRIBUTION OF THE POLLUTING LOAD OF SWINE MANURE ACCORDING TO ITS VARIOUS PHYSICAL COMPONENTS. STUDY OF A SCREENING DEVICE}

Using a mean sample of daily waste from a pig farrowing-fattening house, we determined and analysed the various granulometric fractions, the separation of which was made by screening on holes from 40 to $800 \mu$ and for particles of smaller size than $40 \mu$, by centrifugation at $2200 \mathrm{~g}$ (for $15 \mathrm{mn}$ ).

It was shown that the suspended solids supplied a notable polluting load (COD : 8o p. Ioo; BOD : $5^{8} \mathrm{p}$. IOo) and that the largest particles appeared in the COD and SS measures, but affected only slightly the $\mathrm{BOD}_{5}$ and contained only little nitrogen. The $\mathrm{BOD}_{5}$ was mainly related to dissolved or colloïlal substances and to particles smaller than $\mu 4^{\circ}$.

In the second part of this experiment, we studied the performances of a vibrating screen of the type Contiscreen (diameter : $90 \mathrm{~cm}$ and holes of $400-500 \mu$ ). The optimum operating conditions of this type of screen correspond to a discontinuous feeding at a flow rate as high as possible to permit formation, at each operating period, of a cake of screening refuse playing the role of a pre-layer. This cake is then drained and evacuated after stopping of the feeding. However, too high flow rates or prolonged feeding lead to obstruction of the screen.

This type of screen eliminates 36 to $52 \mathrm{p}$. Ioo of solids representing a COD loading of $\mathrm{I}$ to 1.2 gram per gram.

\section{ÉPUHATION DES EFFLUENTS DE PORCHERIES ANNEXÉS A DES FROMAGERIES}

\author{
D. BALLAY et N. STAMBOULI* \\ Centre technique du Génie rural, des Eaux et des Forêts (C. T. G. R. E. F.), \\ Division Qualité des Eaux, \\ 14, Av. de Saint-Mandé, \\ 75012 Paris \\ * Institut technique du Porc (I. T. P.), (détaché au C. T. G, R. E. F.)
}

\section{RÉSUMÉ}

Plusieurs campagnes de mesures ont été effectuées sur deux porcheries d'engraissement de I 600 et 4000 places où les porcs sont alimentés avec le lactosérum produit par une fromagerie voisine, afin de déterminer le volume et la charge polluante des effluents, en s'efforçant de les relier aux conditions d'alimentation des animaux. 